Arq. Bras. Med. Vet. Zootec., v.69, n.4, p.821-829, 2017

\title{
Cloprostenol administration in the first week postpartum reduces expression of oxytocin receptors in the endometrium in Holstein-Zebu cows
}

\author{
[Administração de cloprostenol na primeira semana pós-parto pode reduzir a expressão de receptores de \\ ocitocina no endométrio de vacas mestiças Holandês-Zebu] \\ A. Camargos ${ }^{1}$, S. Wohlres-Viana ${ }^{2}$, I.F. Costa ${ }^{3}$, L.S. Camargo ${ }^{2}$, J.C. Ferreira ${ }^{3}$, \\ A.A. $\operatorname{Ramos}^{3}$ (in memorian), E. $\mathrm{Oba}^{3}$ \\ ${ }^{1}$ Instituto Federal Goiano - IF Goiano - Morrinhos, GO \\ ${ }^{2}$ Empresa Brasileira de Pesquisa Agropecuária - Embrapa - Juiz de Fora, MG \\ ${ }^{3}$ Universidade Estadual Paulista "Julio de Mesquita Filho" - Unesp - Botucatu, SP
}

\begin{abstract}
The present study investigated the hormonal profile and expression of prostaglandin $\mathrm{F}_{2 \alpha}\left(\mathrm{PGF}_{2 \alpha}\right)$, oxytocin and estrogen receptors in uterine tissues of postpartum cows treated with cloprostenol. Twenty HolsteinZebu crossbred cows were treated with saline solution (treatment CONT) or cloprostenol (treatment CLO), both administered two and five days postpartum. Blood samples were collected on days two, seven, 14, 21 and 28 postpartum for progesterone, $\mathrm{PGF}_{2 \alpha}$ metabolite (PGFM) and estradiol determination, and endometrial biopsy was performed in order to quantify the expression of oxytocin receptor (OXTR), prostaglandin $\mathrm{F}$ receptor (PTGFR) and estrogen receptor 1 (ERS1) genes. In the CLO treatment, expression of OXTR was reduced $(\mathrm{P}<0.05)$ but no difference $(\mathrm{P}>0.05)$ between treatments was found for $P T G F R$ and ERS1 expression. Estrogen concentrations increased progressively until day $14(\mathrm{P}<0.05)$ and the highest OXTR expression and lowest PTGFR expression were observed on day $14(\mathrm{P}<0.05)$ in both treatments. Serum PGFM concentrations were high throughout the experiment. In conclusion, cloprostenol administration at days two and five of postpartum seems to reduce OXTR expression in the endometrium in crossbred cows.
\end{abstract}

Keywords: PTGFR, ESR1, progesterone, estradiol, RT-PCR

\section{RESUMO}

O presente estudo avaliou o perfil hormonal e a expressão gênica de receptores de prostaglandina $F_{2 \alpha}$ $\left(P G F_{2 a}\right)$, ocitocina e estrógeno no endométrio de vacas pós-parto tratadas com cloprostenol. Vinte vacas mestiças Holandês-Zebu foram tratadas com solução salina (tratamento CONT, $n=10$ ) ou cloprostenol (tratamento $C L O, n=10$ ), ambos administrados dois e cinco dias após o parto. Amostras de sangue foram coletadas nos dias dois, sete, 14, 21 e 28 pós-parto para mensuração de progesterona, de metabólito de $P G F_{2 \alpha}(P G F M)$ e de estradiol, e foram obtidas biópsias endometriais para quantificar a expressão de PTGFR, OXTR e ESR1. No tratamento CLO, a expressão gênica de receptores de ocitocina foi menor $(P<0,05)$. As concentrações de estrógeno aumentaram progressivamente até o dia 14 $(P<0,05)$. A maior expressão de OXTR foi observada no dia $14(P<0,05)$. A expressão de ESR1 foi semelhante entre os tratamentos $(P>0,05)$. Os niveis de PGFM foram altos durante todo o estudo. Conclui-se que a administração de cloprostenol nos dias dois e cinco pós-parto parece diminuir a expressão de OXTR no endométrio em vacas mestiças.

Palavras-chave: PTGFR, ESR1, progesterona, estradiol, RT-PCR

Recebido em 28 de novembro de 2016

Aceito em 3 de dezembro de 2016

E-mail: aline.camargos@ifgoiano.edu.br 


\section{INTRODUCTION}

Postpartum release of substantial amounts of prostaglandin $\mathrm{F}_{2 \alpha}\left(\mathrm{PGF}_{2 \alpha}\right)$ matches the period of uterine involution (Kindahl et al., 1999). To accelerate involution in healthy animals and in those with puerperal pathology, different protocols for postpartum application of $\mathrm{PGF}_{2 \alpha}$ analogues have been developed; the most common are those with two injections of 0.530 $\mu \mathrm{g}$ of cloprostenol sodium in the first week postpartum with two or three day intervals (Nakao et al., 1997; Fernandes et al., 2012; Haimerl et al., 2012).

Some studies, however, report that an increase in serum $\mathrm{PGF}_{2 \alpha}$ metabolite (PGFM) concentrations does not account for uterine involution (Nakao et al., 1997; Salasel and Mokhtari, 2011). Indeed, data on the association between the time PGFM remains at high concentrations and the time required for complete uterine involution are controversial (Nakao et al., 1997; Kindahl et al., 1999).

Few studies have investigated how other reproductive hormones that affect uterine tone (oxytocin and progesterone) act in postpartum involution. In addition, outcome data of prostaglandin-based protocols regarding the hormonal profile of crossbred cows in the postpartum period are not available (Salasel and Mokhtari, 2011; Haimerl et al., 2012).

Researchs in the field of molecular biology indicate a variation in the expression of many uterine receptors and reproductive hormones according to the cow's reproductive stage (Meikle et al., 2001; Ronbinson et al., 2001; Arosh et al., 2004; Banu et al., 2005; Martin et $a l ., 2008)$. During pregnancy, the expression of special receptors in uterine tissues remains steady or varies as a function of the type of receptor, tissue and pregnancy stage (Arosh et al., 2004; Banu et al., 2005). There is little information on uterine receptors in puerperium.

The study of reproductive hormonal profile associated with the expression of uterine hormone receptors is a promising pathway for understanding the mechanisms underlying postpartum uterine involution in cows. As such, the present study investigated if postpartum administration of the synthetic prostaglandin cloprostenol to crossbred cows: i) increases of plasmatic PGFM do not affect progesterone and estradiol concentrations; and ii) increases PGF $_{2 \alpha}$ and expression of oxytocin receptor gene does not affect expression of estrogen receptor gene in uterus.

\section{MATERIALS AND METHODS}

The experiment was carried out from January to June 2012 (summer to autumn) on the Santa Fé farm in Óleo, São Paulo state (2256'29”S; $49^{\circ} 20^{\prime} 31^{\prime \prime} \mathrm{W}$; $682 \mathrm{~m}$ altitude). The project was approved by the Animal Research Ethics Committee of the School of Veterinary Medicine and Animal Science of São Paulo State University (UNESP) under protocol No. 196/2010.

The $1 / 2$ Holstein-Nelore crossbred herd consisted of 20 healthy pregnant cows with one to eight previous deliveries, body condition scores $\geq 3.5$ $(0-5$ point scale; Wildman et al, 1982) and average daily milk production of $17 \mathrm{~L}$. The animals were kept in isolated paddocks for parturition monitoring. A diet composed of Panicum maximum grass, barley, mineral supplement and water was provided ad libitum.

All animals included in the study presented normal parturition without placental retention, that is, expulsion of fetal annexes within $12 \mathrm{~h}$ postpartum.

After parturition (D0), the cows were randomly divided into two treatment groups, that received intramuscular $2 \mathrm{~mL}$ saline solution (CONT treatment; $n=10)$ or $2 \mathrm{~mL}$ cloprostenol sodium $(0.530 \mu \mathrm{g})($ CLO treatment; $n=10)$ on D2 and D5 postpartum.

The groups had same $1 / 2$ crossbred degree, average number of parturitions, age and body condition score. Puerperal infections did not occur in animals in the study.

Blood samples were collected on D2, D7, D14, D21 and D28 postpartum into heparinized tubes (BD Vacutainer ${ }^{\circledR}$ Plus, USA) for plasma PGFM, estrogen and progesterone determination. The samples were kept in coolers for ten min, centrifuged for $15 \mathrm{~min}$, and the plasma was harvest and obtained were stored in microtubes at $-20^{\circ} \mathrm{C}$. until analysis. 
Estrogen and progesterone concentrations were determined by radioimmunoassay (RIA), using commercial kits (Coat-a-Count ${ }^{\circledR}$ Siemens, Los Angeles, CA, USA), according to manufacturer's instructions. Tube radioactivity of the cell pellets was measured with a gamma counter (Cobra II Auto Gamma, Packard ${ }^{\circledR}$, MN, USA). Estrogen assay sensitivity was $0.22 \mathrm{pg} / \mathrm{mL}$, intra-assay variation $12.8 \%$ and inter assay variation $14.1 \%$. For the progesterone assay, sensitivity was $0.04 \mathrm{ng} / \mathrm{mL}$ and intra and inter-assay coefficients 6.0 and $6.7 \%$, respectively.

PGFM determination was performed by enzyme immunoassay (EIA) using a commercial kit (DetectX 13, 14-dihydro-15-keto-PGF ${ }_{2 \alpha}{ }^{\circledR}$, Arbor Assays, MI, USA), according to manufacturer's instructions. Assay sensitivity was $0.02 \mathrm{ng} / \mathrm{mL}$, and intra and inter-assay variation were 7.35 and $5.81 \%$, respectively.

Following gynecological examination, endometrial layer samples were collected at D2, D7 and D14 postpartum from eight cows of each group. Endometrial biopsies were performed with a Yomann biopsy nipper (Hauptner ${ }^{\circledR}$, Solingen, Germany) for further analysis of gene expression. The tissue fragments were washed in phosphate-buffered saline (PBS 1x, LGC Biotecnology, SP, Brazil) and placed into microtubes containing a solution to stabilize and protect cell RNA (RNA later ${ }^{\circledR}$, Life Technologies, CA, USA). The tubes were kept cool for $24 \mathrm{~h}$ and then stored at $-80^{\circ} \mathrm{C}$.

After thawing and removing from RNA later, endometrial samples were macerated and total
RNA extraction performed by RNEasy Mini Kit (Qiagen, Hilden, Germany), according to manufacturer's instructions, and treated with DNAse to prevent DNA contamination. The RNA was quantified in a spectrophotometer (ND-100 Nanodrop, Wilmington, DE, USA). Samples presenting 260/280 ratio between 1.7 and 2.0 were considered appropriate for expression analysis. Reverse transcription was performed using the commercial Superscript III First-Strand Synthesis Supermix kit (Invitrogen, Carlsbad, CA, USA), according to the manufacturer specifications. The samples were stored at $-80^{\circ} \mathrm{C}$ until PCR was performed.

The relative quantification of oxytocin receptor $(O X T R)$, prostaglandin $\mathrm{F}$ receptor $(P T G F R)$ and estrogen receptor 1 (ERS1) transcripts were evaluated. Beta-actin (ACTB) and glyceraldehyde 3-phosphate dehydrogenase $(G A P D H)$ were used as reference endogenous genes. Real time PCR was performed using the Power SYBR Green PCR Master Mix kit (Applied Biosystems, Foster City, CA, USA), according to the manufacturer's instructions. The amount of cDNA and primers was defined based on those that reached the optimization process with higher efficiency. Efficiency was calculated based on the fluorescence emitted during each cycle using the LinRegPCR software (Ramakers et al., 2003). The primer efficiency was 1.90 , 1.87, 1.86, 1.92 and 1.84 for $A C T B, G A P D H$, $O X T R, P T G F R$ and ERS1, respectively. Samples were run in duplicates in a $25 \mu \mathrm{L}$ volume reaction in the ABI PRISM 7300 Sequence Detection Systems (Applied Biosystems).

Table 1. Primer sequences used for relative gene expression analysis by RT-PCR

\begin{tabular}{|c|c|c|c|c|}
\hline $\begin{array}{c}\text { Gene } \\
\text { symbol }\end{array}$ & Primer Sequence ( $\left.5^{\prime}-3^{\prime}\right)$ & $\begin{array}{c}\text { Annealing } \\
\text { temperature } \\
\left({ }^{\circ} \mathrm{C}\right)\end{array}$ & $\begin{array}{l}\text { Fragment } \\
\text { Size (bp) }\end{array}$ & $\begin{array}{l}\text { GenBank Accession } \\
\text { Number or Reference }\end{array}$ \\
\hline$A C T B$ & $\begin{array}{l}\text { F-GACATCCGCAAGGACCTCTA } \\
\text { R-ACATCTGCTGGAAGGTGGAC }\end{array}$ & 53 & 205 & NM_173979 \\
\hline$G A P D H$ & $\begin{array}{l}\text { F-CCAACGTGTCTGTTGTGGATCTGA } \\
\text { R-AGCTTGACAAAGTGGTCGTTGAG }\end{array}$ & 53 & 217 & Mourot et al. (2006) \\
\hline OTXR & $\begin{array}{l}\text { F- CCAAGGAAGCCTCACCTTTC } \\
\text { R- GTGGCCCGTGAAGAGCAT }\end{array}$ & 58 & 92 & NM_174134.2 \\
\hline PTGFR & $\begin{array}{l}\text { F- CAAGCACAGTGAAATGGGGC } \\
\text { R- CTGTGACATGACAACGCACG }\end{array}$ & 58 & 92 & NM_181025.3 \\
\hline ERS1 & $\begin{array}{l}\text { F- AATGATGGGCTTGCTGACCA } \\
\text { R- AGGATCTCTAGCCAGGCACA }\end{array}$ & 58 & 138 & NM_001001443.1 \\
\hline
\end{tabular}


The PCR conditions were $95^{\circ} \mathrm{C}$ for two min; 40 cycles of $95^{\circ} \mathrm{C}$ for $15 \mathrm{sec}$; primer specific annealing temperature (Tab. 1) for $30 \mathrm{sec}$ followed by $60^{\circ} \mathrm{C}$ for $30 \mathrm{sec}$. To avoid plate-toplate variation, we designed plates using all the samples and one primer set per plate. After each PCR run, a melting curve analysis was performed to confirm that a single specific product was generated. No-template controls (NTC), comprised of the PCR reaction mix without nucleic acid, were also run with each primer to confirm the absence of contaminations. Calculations of relative quantification for every target gene were performed by the comparative CT method, taking primer efficiency into consideration and using the sample with lowest value found in the Control group as calibrator. Values are shown as n-fold (mean \pm SEM) difference relative to the calibrator sample.

Data were analyzed by GLM ANOVA (PROC GLM, SAS Institute, 2009). The sources of variation taken into consideration were treatment (CONT and CLO); postpartum day (D2, D7, D14, D21, D28); and treatment vs day interaction. Means of hormone concentrations were contrasted through Tukey's test. Means of relative gene expression were contrasted by Student-Newman-Keul's test. Differences were considered significant at the $95 \%$ confidence level $(\mathrm{P}<0.05)$.

\section{RESULTS AND DISCUSSION}

Age and body condition score of the cows were similar between treatments $(\mathrm{P}>0.05)$ throughout the experiment. Serum progesterone concentration did not change in response to cloprostenol administration in all the days evaluated $\quad(\mathrm{P}>0.05)$. However, mean concentrations were low until day 14 and then increased progressively. Fig. 1 shows mean progesterone concentrations at D2, D7, D14, D21, D28 postpartum.

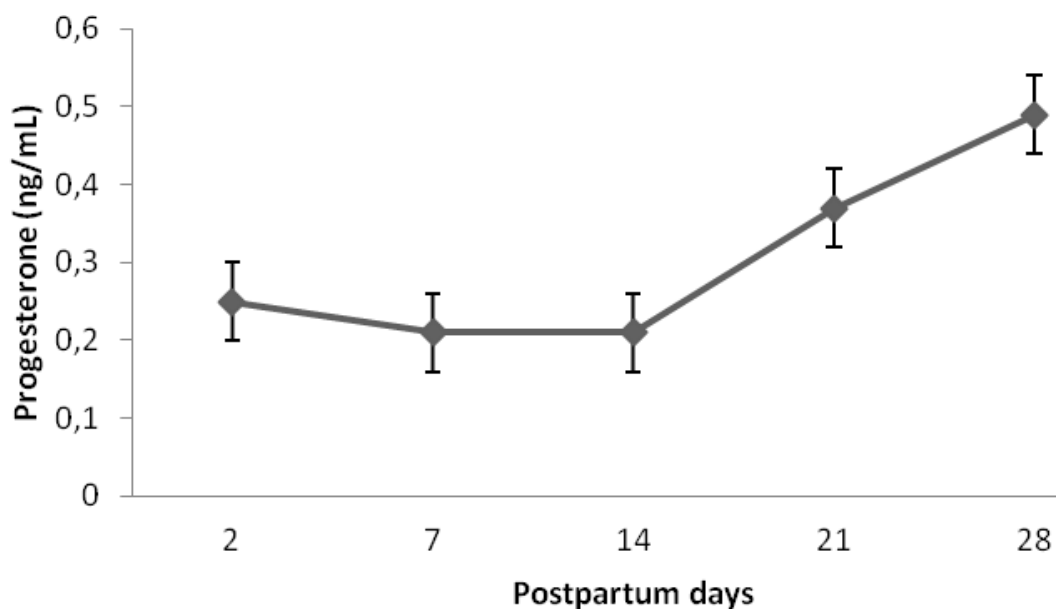

Figure 1. Mean $( \pm \mathrm{SD})$ postpartum plasma progesterone concentration in Holstein-Zebu crossbred cows, determined by radioimmunoassay. No statistical differences between the treatments or days were observed ( $\mathrm{P}>0.05$, Tukey's test).

During pregnancy, progesterone is continuously secreted by the corpus luteum and placenta, but secretion interruption during prepartum luteolysis lowers progesterone concentration drastically in the postpartum period. Only when cyclic ovarian activity resumes, with the development of a new corpus luteum, progesterone is produced again, increasing its concentration in bloodstream (Lamming et al., 1979). Thus, progesterone is an important signaler of ovarian activity, and increase in progesterone concentrations may indicate the resumption of cyclic ovarian activity.

Estradiol concentrations did not differ between treatments $(\mathrm{P}>0.05)$, but they were different among treatment days $(\mathrm{P}<0.05)$, as shown in Fig. 2. The lowest estradiol concentrations were observed at D2 days postpartum, increasing progressively until D14. From that point on, estradiol concentrations remained high until D28. 


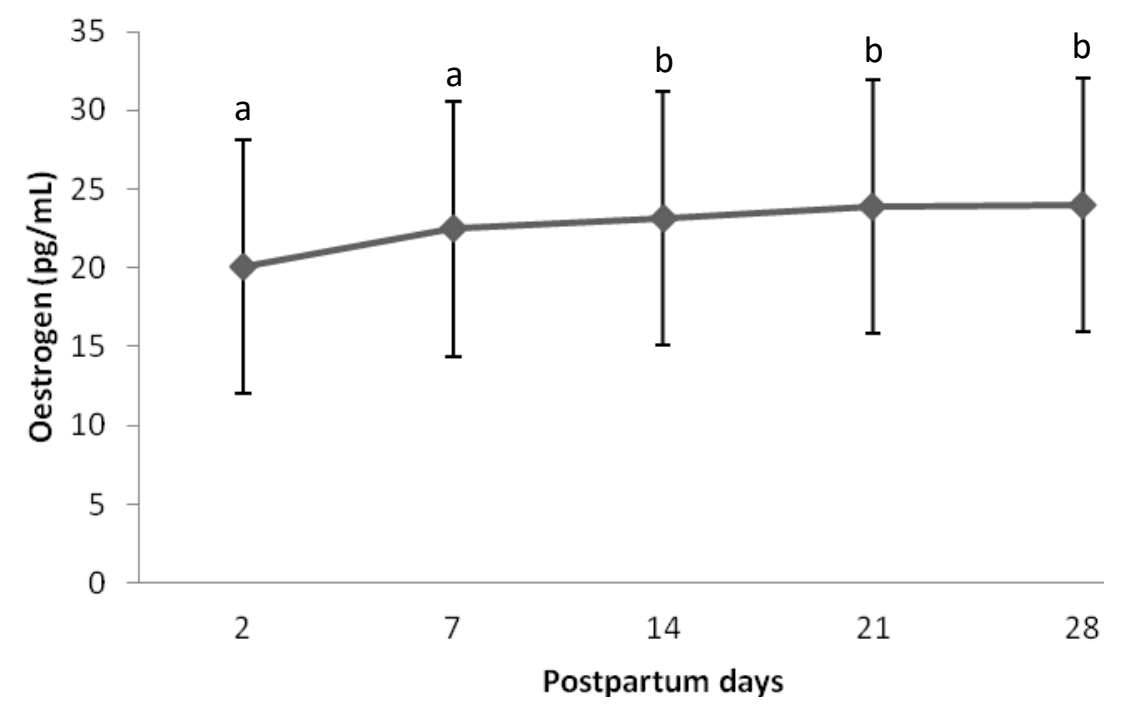

Figure 2. Mean $( \pm \mathrm{SD})$ postpartum plasma estradiol concentration in Holstein-Zebu crossbred cows. Different letters indicate statistical differences between the days of examination $(\mathrm{P}<0.05$, Tukey's test).

Estradiol dynamics in the postpartum period was different to that exhibited by progesterone. Between D2 and D14, progesterone concentrations were unchanged, while estradiol concentrations increased progressively. From D14 to D28, estradiol concentrations were stable, whereas progesterone increased progressively.
PGFM concentrations between D2 and D28 postpartum are depicted in Fig. 3. Injection of the synthetic $\mathrm{PGF}_{2 \alpha}$ analogue did not change serum PGFM concentrations $(\mathrm{P}>0.05)$ These concentrations remained high during the evaluation period, with no statistical differences over time $(\mathrm{P}>0.05)$, but with a tendency to decline between D21 and D28 postpartum.

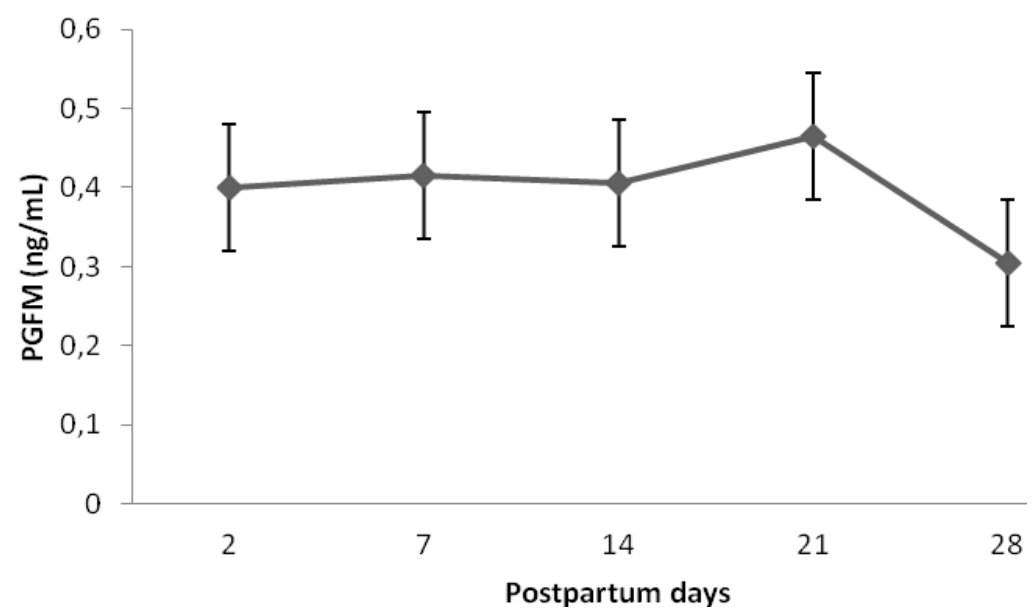

Figure 3. Mean $( \pm \mathrm{SD})$ postpartum plasma Prostaglandin F 2 alpha metabolite concentrations (PGFM) (mean \pm SD) in Holstein-Zebu crossbred cows, determined by enzyme immunoassay. No statistical differences between the treatments or days were observed ( $\mathrm{P}>0.05$, Tukey's test).

According to Toribio et al. (1994), from delivery to resumption of ovarian activity, the hormonal profile is characterized by high $\mathrm{PGF}_{2 \alpha}$ concentrations, produced primarily in the uterus.
In the physiological process of placental detachment and expulsion in cows, $\mathrm{PGF}_{2 \alpha}$ is released before labor begins, and accounts for prepartum luteolysis. After delivery, in the early 
puerperal phase, the predominant endocrine event is the release of large amounts of prostaglandin, due mainly to the action of prostaglandins in inflammatory process because of high prevalence of bacterial contamination. High $\mathrm{PGF}_{2 \alpha}$ concentrations prevent the ovaries from beginning the cyclic activity itself (Kindahl et al., 1992; Jainudeen and Hafez, 1995), intensifying uterine involution (Kindhal et al., 1999; Fernandes et al., 2003).

The period of highest $\mathrm{PGF}_{2 \alpha}$ release identified in the present study was up to 14 days postpartum, corresponding to lower estradiol and progesterone concentrations. According to Kindahl et al. (1992), postpartum ovulation cannot occur before $\mathrm{PGF}_{2 \alpha}$ release is interrupted or close to basal concentrations, which in cattle takes place after the fourth week postpartum. Corroborating this finding, after 21 days postpartum the cows under study exhibited a decrease in $\mathrm{PGF}_{2 \alpha}$ release, evidenced by a decrease in PGFM concentrations. During this period, no occurrence of the first postpartum ovulation was observed.

The expression of $O X T R$ gene in endometrial samples of cows receiving cloprostenol (CLO) or saline solution (CONT) is shown on figure 4 . The expression of OXTR gene was higher $(\mathrm{P}<0.05)$ at day 14 than at day two and seven postpartum in the CONT group. Also, the expression of OXTR was higher $(\mathrm{P}<0.05)$ in CONT than in CLO group at day 14 postpartum, with no difference $(\mathrm{P}>0.05)$ on days before. Those finding in the CONT group indicate that the expression of OXTR gene physiologically increases between day seven and 14 postpartum. This is corroborated by previous immunohistochemical study that did not find expression of $O X T R$ at day two postpartum, but by day five there was an apparent increase and by day seven it was possible to detected OXTR expression in all uterine layers (Perumamthadathil et al., 2014).

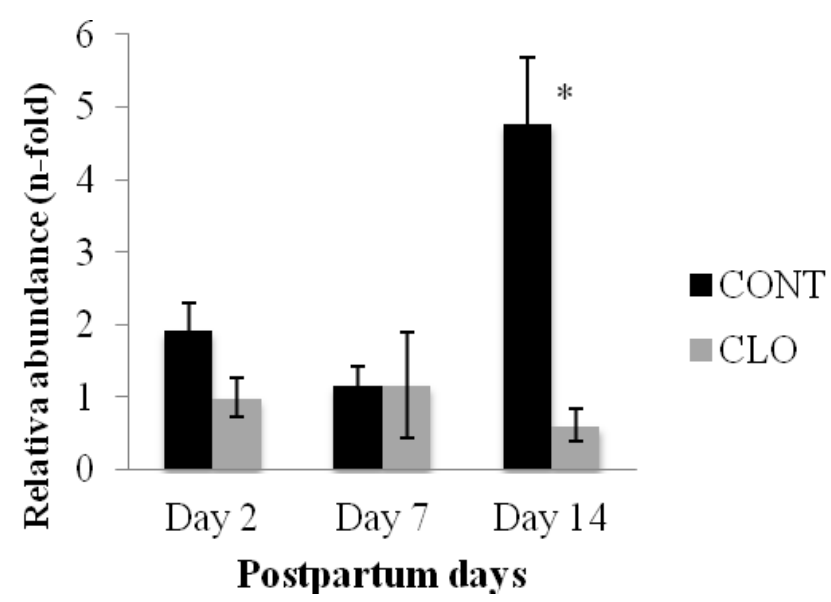

Figure 4. Mean $( \pm$ SEM) postpartum gene expression of endometrial oxytocin receptor $(O X T R)$. The treatments were: control (CONT $-2 \mathrm{~mL}$ of saline i.m. on D2 and D5 postpartum) and cloprostenol (CLO - $530 \mu \mathrm{g}$ of cloprostenol sodium i.m. on D2 and D5 postpartum). The relative amounts of mRNA were determined by real time PCR and values are shown as n-fold relative to the calibrator sample. Asterisk $(*)$ indicates differences among columns $(\mathrm{P}<0.05$, Student Newman-Keuls's test).

Moreover, the increase of $O X T R$ gene expression in endometrium from D7 to D14 postpartum is consistent with the hormonal profiling found in the cows. Progesterone has a suppressive role on expression of oxytocin receptor whereas estradiol has a stimulating effect (Vallet et al., 1990, Bishop et al., 2013), despite both being required for appropriated expression. In this present study, the concentration of serum progesterone was low during the 28 postpartum days, although it started increasing after D14, whereas the estradiol concentrations increased between D7 and D14 postpartum. The progesterone and estradiol secretions between D7 and D14 postpartum may have favored the overexpression of OXTR gene in the endometrium when compared to the days before. 
The most interesting finding is the downregulation of $O X T R$ expression at D14 postpartum of cows injected with cloprostenol sodium on D2 and D5 postpartum. One role of oxytocin and its receptor is to stimulate the formation and secretion of prostaglandin in different tissues, including PGF2 $\alpha$ in the endometrium (Blanks and Thornton, 2003). The lower expression of OXTR gene in CLO group suggests that the cows treated with this PGF $2 \alpha$ analogue have low concentrations of endogenous prostaglandin secretion. Nevertheless, the concentrations of PGF $2 \alpha$ metabolites (PGFM) were not different between CLO and CONT groups in any day evaluated, indicating that the concentration of $\mathrm{PGF} 2 \alpha$ circulating in CLO group was kept by the analogue injected in the cows. It is possible that a regulation mechanism exists to avoid high concentrations of PGF $2 \alpha$ circulating during the early postpartum and because of that we could not find an increase of PGFM circulating in the cows treated with cloprostenol. We speculate that if such mechanism exists, it involves the expression of $O X T R$ gene. When healthy dairy cows at very early postpartum periods receive exogenous PGF $2 \alpha$, the expression of OXTR gene is downregulated, as found in the present study, and this low expression contributes to decrease the secretion of endogenous PGF $2 \alpha$, keeping the PGMF circulating in an appropriated concentration.

The nine days between the cloprostenol injection in CLO group and the OXTR expression decrease is not clear and has to be more studied.

Unlike $O X T R$, the expression of PTGFR was similar between treatments $(\mathrm{P}>0.05$; Fig. 5$)$ in all postpartum days evaluated.

\section{Expression of PTGFR gene}

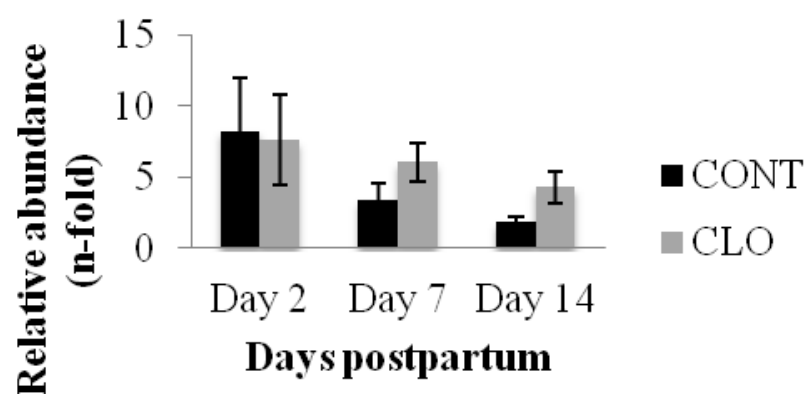

Figure 5. Mean $( \pm$ SEM) postpartum gene expression of endometrial prostaglandin $\mathrm{F} 2 \alpha$ receptor $(P T G F R)$. The treatments were: control (CONT $-2 \mathrm{~mL}$ of saline i.m. on D2 and D5 postpartum) and cloprostenol (CLO - 530 $\mu \mathrm{g}$ of cloprostenol sodium i.m. on D2 and D5 postpartum). The relative amounts of mRNA were determined by real time PCR and values are shown as n-fold relative to the calibrator sample. No statistical differences between the treatments or days were observed ( $\mathrm{P}>0.05$, Student Newman-Keuls's test).

The absence of cloprostenol effect on PTGFR gene expression contrasts to the finding reported to Nellore breed, where higher expression of $P T G F R$ was detected in endometrium at day 14 postpartum in cows receiving cloprostenol at day one and four postpartum (Moraes et al., 2015). Such contrasting findings may be due to the physiological differences in the puerperium between beef and dairy breeds. For instance, beef cows generally show higher uterine score in the postpartum than dairy cows (Carthy et al., 2014).
The expression of the ESR1 gene was similar between treatments and among postpartum days $(\mathrm{P}<0.05$; Fig. 6). Expression of ESRl in the cow's uterine endometrium is regulated by estradiol during the preovulatory phase and in ovine's uterine endometrium an increase in ESR 1 expression precedes the increase of $O X T R$ expression (Bridges et al., 2013). Indeed, the ovine ESR1 plays a role on the regulation of OXTR expression (Fleming et al., 2006). 


\section{Expression of ESR1 gene}

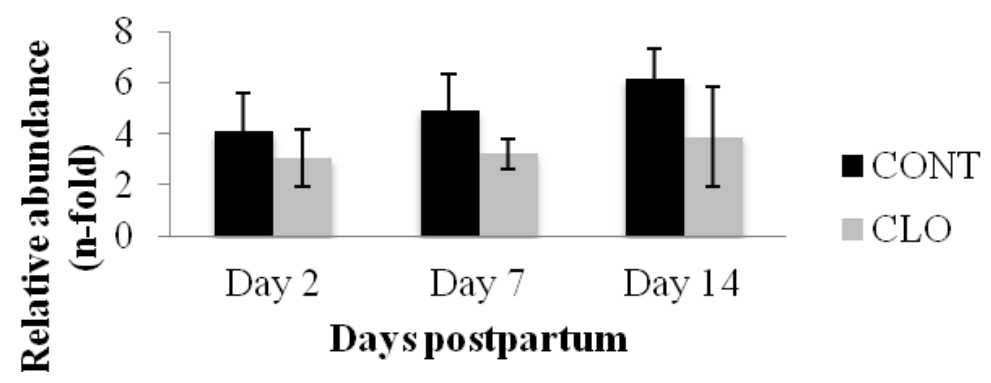

Figure 6. Mean $( \pm \mathrm{SEM})$ postpartum gene expression of endometrial estrogen receptor 1 (ERS1). The treatments were: control (CONT $-2 \mathrm{~mL}$ of saline i.m. on D2 and D5 postpartum) and cloprostenol (CLO $-530 \mu \mathrm{g}$ of cloprostenol sodium i.m. on D2 and D5 postpartum). The relative amounts of mRNA were determined by real time PCR and values are shown as n-fold relative to the calibrator sample. No statistical differences between the treatments or days were observed $(\mathrm{P}>0.05$, Student Newman-Keuls's test).

One interesting finding is that the increase of $O X T R$ gene expression may not be preceded by an increase of ESRl gene expression in bovines, because on day 14 postpartum we found an higher expression of OXTR gene but only subtle increase of ESRl gene. Similar finding was reported by in situ hybridization study with bovine endometrium but during oestrous cycle and early pregnancy (Robinson et al., 2001). However, it is not clear whether a minimal increase of expression of ESR I gene would have an effect on expression of $O X T R$ gene.

Similar to the expression of PTGRF gene, injection of cloprostenol during the early postpartum period of healthy cows has no effect on expression of ESRl gene in the endometrium. In rabbits, it was reported that PGF $2 \alpha$ injection decreased the luteal expression of ESRl gene (Maranesi et al., 2010), but our study with bovine postpartum endometrium suggests that injections of PGF $2 \alpha$ analogue has no influence on expression of ESR1 gene.

\section{CONCLUSIONS}

In conclusion, injection of cloprostenol, a PGF $2 \alpha$ analog, in Holstein-Zebu crossbred cows in the early postpartum period did not interfere in hormonal profile but it down-regulates the endometrial expression of OXTR gene. This study also provides insights about the interrelationship among expression of $O X T R$, PTGFR and ERS1 genes in bovine endometrium at early postpartum period.

\section{AKNOWLEDGEMENTS}

This research was supported by FAPESP (Grant \#2012/02960-9, CAPES Funding Foundation. for the scholarship and IF Goiano for translation financial support.

\section{REFERENCES}

AROSH, J.A.; BANU, S.K.; CHAPDELAINE, P.; FORTIER, M.A. Temporal and tissue-especific expression of prostaglandin receptors EP2, EP3, EP4, FP, and ciclooxygenses 1 and 2 in uterus and fetal membranes during bovine pregnancy. Endocrinology, v.145, p.407-417, 2004.

BANU, S.K.; AROSH, J.A.; CHAPDELAINE, P.; FORTIER, M.A. Expression of prostaglandin transporter in the bovine uterus and fetal membranes during pregnancy. Biol. Reprod., v.73, p.230-236, 2005.

BISHOP, CV. Progesterone inhibition of oxytocin signaling in endometrium. Front. Neurosci., v.7, p.77138, 2013.

BLANKS, A.M.; THORNTON S. The role of oxytocin in parturition. Br. J. Obstet. Gynaecol., 110, v.20, p.46-51, 2003.

BRIDGES, G.A.; DAY, M.L.; GEARY, T.W.; CRUPPE, L.H. Deficiencies in the uterine environment and failure to support embryonic development. J. Anim. Sci., v.91, p.3002-3013, 2013.

CARTHY, T.R.; BERRY, D.P.; FITZGERALD, A. et al. Risk factors associated with detailed reproductive phenotypes in dairy and beef cows. Animal, v.8, p.695-703, 2014. 
FERNANDES, C.A.C.; ALVES, B.F.L.; OLIVEIRA, E.R. et al. Efeito de diferentes doses de cloprostenol sódico no período pós-parto de vacas de corte. Ciênc. Anim. Bras., v.13, p.346-355, 2012.

FERNANDES, C.A.C.; OLIVEIRA, E.R.; VASCONCELOS, T.D. Melhoria da performance reprodutiva em vacas de corte com a aplicação de cloprostenol no pós-parto. Rev. Bras. Reprod. Anim., v.27, p.432-436, 2003.

FLEMING， J.G.; SPENCER, T.E.; SAFE, S.H.; BAZER, F.W. Estrogen regulates transcription of the ovine oxytocin receptor gene through GC-rich SP1 promoter elements. Endocrinol, v.147, p.899-911, 2006.

HAIMERL, P.; ARLT, S.; HEUWIESER, W. Evidence-based medicine: quality and comparability of clinical trials investigating the efficacy of prostaglandin F2 $\alpha$ for the treatment of bovine endometritis. J. Dairy Sci., v.73, p.287-296, 2012.JAINUDEEN, M.R.; HAFEZ, S.E. Gestação, fisiologia pré-natal e parto, In: HAFEZ, E.S.E. (Ed.). Reprodução animal. 6.ed. Barueri: Manole, 1995. p.217-240.

KINDHAL, H.; BEKANA, M.; KASK, K. Endocrine aspects of the uterine involution in the cow. Reprod. Dom. Anim., v.34, p.199-205, 1999.

LAMMING, G.E.; FOSTER, J.P.; BULMAN, D.C. Pharmacological control of reproduction cycles. Vet. Rec., v.104, p.156-160, 1979.

MARANESI, M.; ZERANI, M.; LILLI, L. et al. Expression of luteal estrogen receptor, interleukin-1, and apoptosis-associated genes after PGF2alpha administration in rabbits at different stages of pseudopregnancy. Domest. Anim. Endocrinol., v.39, p.116-130, 2010

MARTIN, I.; TORRES NETO, R.; OBA, E. et al.. Immunohistochemical detection of receptors for oestrogen and progesterone in endometrial glands and stroma during the oestrous cycle in Nelore (Bos taurus indicus) cows. Reprod. Domest. Anim. v,43, p.415-21, 2008

MEIKLE, A.; SAHLIN, L.; FERRARIS, A. et al. Endometrial mRNA expression of oestrogen receptor, progesterone receptor and insulin-like growth factor I throughout the bovine oestrous cycle. Anim. Reprod. Sci., v.68, p.45-56, 2001.
MORAES, C.N.; MAIA, L.; LIMA, P.F. et al. Temporal analysis of prostaglandin F2alfa receptor, caspase 3, and cyclooxygenase 2 messenger RNA expression and prostaglandin F2alfa receptor and cyclooxygenase 2 protein expression in endometrial tissue from multiparous Nelore (Bos Taurus indicus) cows treated with cloprostenol sodium during puerperium. Theriogenology, v.83, p.276-284, 2015.

MOUROT, M.; DUFORT, I.; GRAVEL, C. et al. The influence of follicle size, FSH-enriched maturation medium, and early cleavage on bovine oocyte maternal mRNA levels. Mol. Reprod. Dev., v.73, p.1367-1379, 2006.

NAKAO, T.; GAMAL, A.; OSAWA, T. et al. Postpartum plasma PGF metabolite profile in cows with dystocia and/or retained placenta, and effect of fenprostalene on uterine involution and reproductive performance. J. Vet. Med. Sci., v.59, p.791-794, 1997.

PERUMAMTHADATHIL, C.S.; JOHNSON, W.H.; LEBLANC, S.J. et al. Persistence of oxytocin receptors in the bovine uterus during the first $7 \mathrm{~d}$ after calving: an immunohistochemical study. Can. J. Vet. Res., v.78, p.72-77, 2014.

RAMAKERS, C.; RUIJTER, J.M.; DEPREZ, R.H.; MOORMAN, A.F. Assumption-free analysis of quantitative real-time polymerase chain reaction (PCR) data. Neurosci. Lett., v.339, p.62-66, 2003.

ROBINSON, R.S.; MANN, G.E.; LAMMING, G.E.; WATHES, D.C. Expression of oxytocin, oestrogen and progesterone receptors in uterine biopsy samples throughout the oestrous cycle and early pregnancy in cows. Reproduction, v.122, p.965-979, 2001.

SALASEL, B.; MOKHTARI, A. Effect of early postpartum PGF2 $\alpha$ treatment on reproductive performance in dairy cows with calving and puerperal traits. Theriogenology, v.76, p.1723-1729, 2011.

Statistical analysis system. Versão 9.2. Cary: SAS Institute, 2009.

TORIBIO, J. Blood levels of the prostaglandin F2alpha metabolite during the postpartum period in Bos indicus cows in the humid tropics. J. Vet. Med., v.41, p.630-639, 1994.

VALLET, J.L.; LAMMING, G.E.; BATTEN, M. Control of endometrial oxytocin receptor and uterine response to oxytocin by progesterone and oestradiol in the ewe. J. Reprod. Fertil., v.90, p.625-34, 1990.

WILDMAN, E.E.; JONES, G.M.; WAGNER, P.E. et al. A dairy cow body condition scoring system and its relationship to selected production characteristics. $J$. Dairy Sci., v.65, p.495-501, 1982. 